\title{
(2) OPEN ACCESS \\ Pneumocystis in metastatic lung cancer, a pragmatic approach in support of prophylaxis
}

\author{
David Luque Paz, ${ }^{1}$ Stephane Jouneau, ${ }^{2}$ Pierre Tattevin, ${ }^{1}$ Charles Ricordel (i) ${ }^{2}$
}

${ }^{1}$ Infectious Diseases and Intensive Care Unit, CHU Rennes, Rennes, France ${ }^{2}$ Department of Respiratory Medicine, Centre Hospitalier Universitaire de Rennes, Rennes, France

\section{Correspondence to}

Dr Charles Ricordel;

charles.ricordel@chu-rennes.fr

Accepted 7 May 2021

Check for updates

(c) BMJ Publishing Group Limited 2021. Re-use permitted under CC BY-NC. No commercial re-use. See rights and permissions. Published by BMJ.

To cite: Luque Paz D,

Jouneau $S$, Tattevin $P_{1}$

et al. BMJ Case Rep

2021:14:e232895.

doi:10.1136/bcr-2019-

232895

\section{SUMMARY}

Lung cancer prognosis has improved in the last decade, including in patients with brain metastasis. However, few of these patients who receive corticosteroids have a primary prophylaxis for Pneumocystis jirovecii pneumonia (PJP). We report the case of an 80-yearold man diagnosed with non-small cell lung cancer and concomitant symptomatic brain metastases, treated with $50 \mathrm{mg} /$ day of prednisolone without any prophylaxis, who presented an acute PJP. After 72 hours of unsuccessful treatment of PJP, the patient died. In our review of this case and the existing literature, we emphasise the importance of a wide use of prophylaxis for PJP, especially in advanced lung cancer treated with corticosteroid therapy. We discuss this issue and report current evidence for primary prophylaxis by trimethoprim-sulfamethoxazole.

\section{BACKGROUND}

Human pneumocystosis is a fungal infection caused by Pneumocystis jirovecii, a cosmopolitan and opportunistic ubiquitous fungus. $P$. jirovecii pneumonia (PJP) is potentially lethal, developing mainly in the lungs of profoundly immunocompromised patients. HIV infection, organ transplants and haematological malignancies are well-defined risk factors. $^{12}$

A review of the literature provided arguments to consider a pathophysiological association between $P$. jirovecii and the use of corticosteroids, and American Thoracic Society (ATS) guidelines recommend prophylaxis when prednisone doses exceed $20 \mathrm{mg} /$ day for longer than 1 month. ${ }^{3}$

We present a case of a lethal PJP in a patient with metastatic lung cancer who received corticosteroids without prophylaxis.

\section{CASE PRESENTATION}

In August 2015, an 83-year-old HIV-negative, non-smoker Caucasian man was diagnosed with T3N2M0 small cell lung carcinoma. He went into complete remission after six cycles of carboplatin/ etoposide and thoracic radiation (30 Gy with daily fractions of $3 \mathrm{~Gy}$ ).

In December 2016, a stage I (pT1N0M0) right lower lobe lung adenocarcinoma was discovered and treated with lobectomy. The tumour had no EGFR, BRAF or KRAS mutation and no ALK, ROS1, RET rearrangement; only a copy number variation of MET gene (two to three copies). In April 2017, a neurological impairment revealed a frontal brain metastasis. The patient was treated with radiotherapy associated with methylprednisolone initially at $100 \mathrm{mg} /$ day and then reduced to $50 \mathrm{mg} /$ day.

In June 2017, he presented dry cough and shortness of breath associated with self-reported fever. Two days after the first symptoms, he was admitted to hospital. At admission, he had fever $\left(38.2^{\circ} \mathrm{C}\right)$, blood pressure was $108 / 61 \mathrm{~mm} \mathrm{Hg}$, regular pulse of $79 \mathrm{bpm}$, respiration of 18 cycles/min, and $95 \%$ $\mathrm{SpO}_{2}$ with $2 \mathrm{~L} / \mathrm{min}$ of oxygen supplementation. There was no recent chemotherapy, and no immunosuppressive treatment other than corticosteroids.

\section{INVESTIGATIONS}

Blood laboratory tests revealed no cytopenia: haemoglobin concentration $129 \mathrm{~g} / \mathrm{L}$, platelet count $244000 \times 10^{\wedge} 9 / \mathrm{L}$, white cell count $6400 / \mathrm{mm}^{3}$, including neutrophil count $3900 / \mathrm{mm}^{3}$. There was no renal dysfunction with an estimated glomerular filtration rate of $>60 \mathrm{~mL} / \mathrm{min}$. Chest CT scan showed bilateral excavated nodules evoking lung abscesses, associated with diffuse bilateral groundglass opacities (figure 1). A bronchoalveolar lavage (BAL) was immediately performed with good tolerance, for bacteriological and mycological analyses. Blood culture and serum galactomannan antigen were negative.

\section{DIFFERENTIAL DIAGNOSIS}

A posteriori, BAL results revealed the presence of P. jiroveci (with Gomori-Grocott staining, indirect immunofluorescence and positive Pneumocystis PCR at the 21st cycle of amplification), as well as a few colonies of Aspergillus fumigatus in culture, Actinomyces odontolyticus $\left(10^{5} \mathrm{UFC} / \mathrm{mL}\right)$ in culture and Nocardia nova susceptible to trimethoprimsulfamethoxazole (TMP-SMX). ${ }^{4}$

To explain the acute respiratory failure, we discarded the role of $A$. odontolyticus, which is probably a contamination during the BAL procedure. Images of lung abscesses are compatible with $N$. nova, but nocardiosis would not explain the rapid clinical degradation. A. fumigatus could be implicated in respiratory failure, but the patient had no neutropenia and a negative A. fumigatus PCR in BAL, making the possibility of rapidly lethal invasive aspergillosis less likely.

The association of diffuse bilateral ground-glass opacities, very low cycle threshold value of Pneumocystis PCR in BAL, a positive direct examination and a deep hypoxaemia progressing into severe acute respiratory failure are solid arguments to attribute the death of the patient to a PJP, rather than other coinfections. 


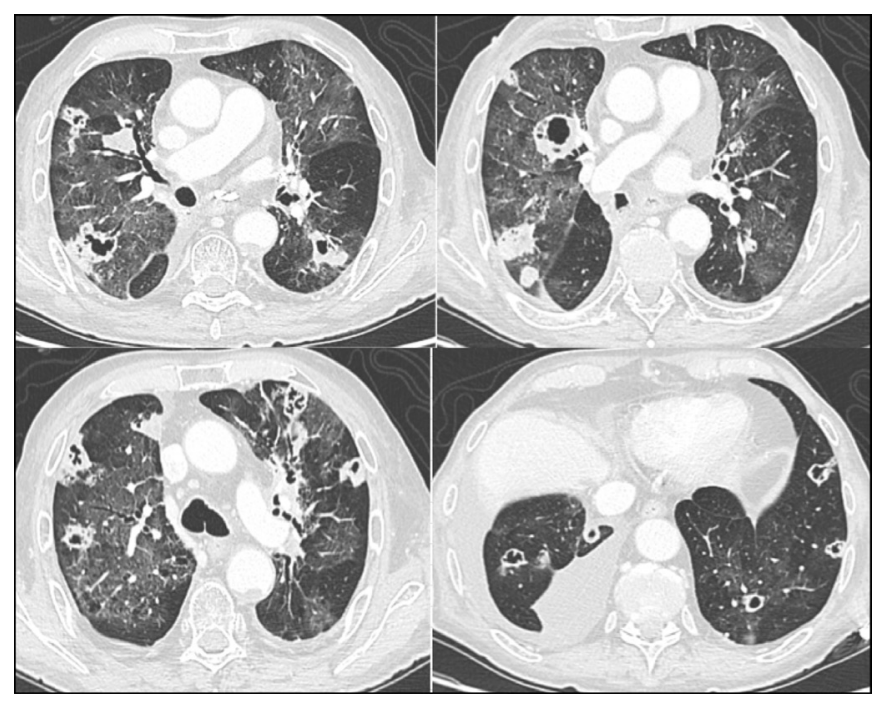

Figure 1 Chest CT scan with bilateral excavated nodules evoking lung abscesses, associated with diffuse bilateral ground-glass opacities.

\section{TREATMENT}

First, the patient was treated with ceftriaxone and rovamycin as recommended for community-acquired pneumonia with comorbidities and severity criteria. After the chest CT, intravenous voriconazole and TMP-SMX treatment was started. Corticosteroids were maintained as adjuvant therapy of hypoxaemic PJP.

\section{OUTCOME AND FOLLOW-UP}

His clinical situation worsened on a respiratory level with increasing oxygen needs. Despite 48 hours of probabilistic treatment, his respiratory failure became critical. On arterial blood gas, he presented an extremely severe hypoxaemia despite oxygen supply (flow rate $15 \mathrm{~L} / \mathrm{min}$ ) with a $\mathrm{PaO}_{2}$ measured at 39 $\mathrm{mm} \mathrm{Hg}$. The patient died on day 3.

\section{DISCUSSION}

In patients with lung cancer, especially with brain metastasis, corticosteroids are commonly prescribed. Life expectancy is limited to a few months or years in most cases, and physicians do not prescribe chemoprophylaxis against Pneumocystis spp. A retrospective study showed that fewer patients with solid tumours $(3.9 \%)$ received prophylaxis compared with patients with haematological malignancies $(63.6 \%))^{5}$

Lung cancer is at low risk of PJP ( $<25$ cases/100 000 patientyear) like other solid tumours, excluding central nervous system cancer. ${ }^{6}$ But for patients having solid cancer and being treated by corticosteroids, the incidence of PJP rises to $1.3 \% .^{7}$ Furthermore, PJP is usually more abrupt and fulminant ${ }^{8}$ among patients with neoplastic disease, and its mortality rate is much higher, approaching $50 \%,{ }^{79}$ and a significant risk factor of mortality with an $\mathrm{OR}=2.66$. In different studies, $55 \%-87 \%$ of patients with PJP had previously used corticosteroids, and 18\%-31\% had a solid tumour. ${ }^{9} 10$ The most important predisposing factor for developing PJP is the use of steroids, even at a low dose (equivalent to $\geq 20 \mathrm{mg} /$ day prednisone for $\geq 1$ month). ${ }^{11} 12$ ATS guidelines recommend prophylaxis when prednisone doses exceed 20 $\mathrm{mg} /$ day for longer than 1 month.

Recent guidelines ${ }^{13}$ and two general reviews ${ }^{14} 15$ recommend prophylaxis for patients with solid cancer receiving prolonged, high-dose corticosteroid treatment (16-25 mg of prednisolone/ day or $\geq 4 \mathrm{mg}$ dexamethasone daily for $\geq 4$ weeks) regardless of the stage of malignancy.

Concerning the toxicity of TMP-SMX, $85 \%$ of the patients do not experience any toxic effects. ${ }^{16}$ So, when steroids are prescribed for a patient with cancer, especially in metastatic diseases, we prioritise a pragmatic attitude: start a prophylaxis if survival exceeds 3 months.

\section{Learning points}

- Corticosteroids are a major risk factor of Pneumocystis jirovecii pneumonia (PJP), adding to the risk of PJP in lung cancer.

- Guidelines recommend PJP prophylaxis by trimethoprimsulfamethoxazole (TMP-SMX) when dose $>20 \mathrm{mg} /$ day.

- Side effects occur in $15 \%$ of cases, and discontinuation of the prophylaxis is required in $3 \%$ of patients treated.

- Our pragmatic proposal: start a primary prophylaxis if surviva exceeds 3 months, and eventually discuss alternatives in case of TMP-SMX intolerance.

Contributors DLP and PT contributed to conception and design of the manuscript. PT and SJ were responsible for the literature review. DLP was responsible for clinical data collection. DLP and CR were responsible for figures. All authors were responsible for manuscript editing and final approval of the article. CR takes responsibility for the paper as a whole.

Funding The authors have not declared a specific grant for this research from any funding agency in the public, commercial or not-for-profit sectors.

Competing interests None declared.

Patient consent for publication Next of kin consent obtained.

Provenance and peer review Not commissioned; externally peer-reviewed.

Open access This is an open access article distributed in accordance with the Creative Commons Attribution Non Commercial (CC BY-NC 4.0) license, which permits others to distribute, remix, adapt, build upon this work non-commercially, and license their derivative works on different terms, provided the original work is properly cited and the use is non-commercial. See: http://creativecommons.org/ licenses/by-nc/4.0/.

\section{ORCID iD}

Charles Ricordel http://orcid.org/0000-0001-6160-2732

\section{REFERENCES}

1 Radhi S, Alexander T, Ukwu M, et al. Outcome of HIV-associated Pneumocystis pneumonia in hospitalized patients from 2000 through 2003. BMC Infect Dis 2008;8:118.

2 Maertens J, Cesaro S, Maschmeyer G, et al. ECIL guidelines for preventing Pneumocystis jirovecii pneumonia in patients with haematological malignancies and stem cell transplant recipients. J Antimicrob Chemother 2016;71:2397-404.

3 Limper AH, Knox KS, Sarosi GA, et al. An official American thoracic Society statement: treatment of fungal infections in adult pulmonary and critical care patients. Am J Respir Crit Care Med 2011;183:96-128.

4 Schlaberg R, Fisher MA, Hanson KE. Susceptibility profiles of Nocardia isolates based on current taxonomy. Antimicrob Agents Chemother 2014;58:795-800.

5 Worth LJ, Dooley MJ, Seymour JF, et al. An analysis of the utilisation of chemoprophylaxis against Pneumocystis jirovecii pneumonia in patients with malignancy receiving corticosteroid therapy at a cancer Hospital. Br J Cancer 2005;92:867-72

6 Fillatre P, Decaux O, Jouneau S, et al. Incidence of Pneumocystis jiroveci pneumonia among groups at risk in HIV-negative patients. Am J Med 2014;127:1242.e11-17.

7 Yale SH, Limper AH. Pneumocystis carinii pneumonia in patients without acquired immunodeficiency syndrome: associated illness and prior corticosteroid therapy. Mayo Clin Proc 1996;71:5-13.

8 Gripaldo R, Lippmann ML. Pneumocystis pneumonia in HIV-negative patients: a review of the literature. Clin Pulmonary Med 2012;19:5-13.

9 Sepkowitz KA, Brown AE, Telzak EE, et al. Pneumocystis carinii pneumonia among patients without AIDS at a cancer Hospital. JAMA 1992;267:832-7.

10 Roblot F, Godet C, Le Moal G, et al. Analysis of underlying diseases and prognosis factors associated with Pneumocystis carinii pneumonia in immunocompromised HIVnegative patients. Eur J Clin Microbiol Infect Dis 2002;21:523-31. 
11 Schoovaerts K, Dirix L, Rutten A, et al. Pneumocystis jiroveci pneumonia (PJP) in nonHIV immunocompromised individuals. Acta Clin Belg 2017;72:413-6.

12 Barbounis V. Should patients with malignancy receive chemoprophylaxis against Pneumocystis jirovecii pneumonia? Nat Clin Pract Oncol 2005;2:490-1.

13 Cooley L, Dendle C, Wolf J, et al. Consensus guidelines for diagnosis, prophylaxis and management of Pneumocystis jirovecii pneumonia in patients with haematological and solid malignancies, 2014. Intern Med J 2014;44:1350-63.
14 Rouyer M, Stoclin A, Blanc F-X. [Pneumocystis pneumonia in HIV-negative adults]. ReV Mal Respir 2015:32:985-90.

15 Roux A, Gonzalez F, Roux M, et al. Update on pulmonary Pneumocystis jiroveci infection in non-HIV patients. Med Mal Infect 2014;44:185-98.

16 Green $\mathrm{H}$, Paul M, Vidal L, et al. Prophylaxis of Pneumocystis pneumonia in immunocompromised non-HIV-infected patients: systematic review and meta-analysis of randomized controlled trials. Mayo Clin Proc 2007;82:1052-9.

Copyright 2021 BMJ Publishing Group. All rights reserved. For permission to reuse any of this content visit https://www.bmj.com/company/products-services/rights-and-licensing/permissions/

BMJ Case Report Fellows may re-use this article for personal use and teaching without any further permission.

Become a Fellow of BMJ Case Reports today and you can:

- Submit as many cases as you like

- Enjoy fast sympathetic peer review and rapid publication of accepted articles

- Access all the published articles

Re-use any of the published material for personal use and teaching without further permission

\section{Customer Service}

If you have any further queries about your subscription, please contact our customer services team on +44 (0) 2071111105 or via email at support@bmj.com.

Visit casereports.bmj.com for more articles like this and to become a Fellow 